AGRARIS: Journal of Agribusiness and Rural Development Research

vol. 6 No. 2: July-December 2020

Article History:

Submitted: January $8^{\text {th }}, 2018$

Accepted: July $20^{\text {th }}, 2020$
Rati Purwasih*, Yudi Sapta Pranoto, Eddy Jajang Jaya Atmaja

Universitas Bangka Belitung, Bangka, Indonesia

*) Correspondence email: ratipurwasih09@gmail.com

\title{
Muntok White Pepper Price Transmission in Bangka Belitung Island Province
}

DOI: https://doi.org/10.18196/agr.6294

\begin{abstract}
The average price of white pepper in the Bangka Belitung Islands Province from January 2007 to December 2016 was IDR 72,531 per $\mathrm{kg}$ on the producer market, IDR 80,622 per $\mathrm{kg}$ on the export market, and IDR 99,017 per $\mathrm{kg}$ on the world market. Based on the data, there is a large marketing margin between the producer market and the export market, IDR 8,091 per $\mathrm{kg}$. While, the margin between the export market and the world market was IDR 18,395 per $\mathrm{kg}$. The present research aims to analyze the transmission of white pepper prices in the Bangka Belitung Islands Province among the three markets. The Asymmetric Error Correction Model (AECM) was used as the model to analyze the transmission of white pepper prices in Bangka Belitung Island Province from producers to exporters, from producers to world market, and from exporters to world market. The transmission of white pepper prices from the three markets shows that in the short period it runs asymmetrically, whereas in the long period it runs symmetrically. Conversely, the transmission of white pepper prices from the world market to the exporters market runs symmetrically in the short term but it runs asymmetrically in the long term.
\end{abstract}

Keywords: AECM, margin, price transmission, white pepper

\section{INTRODUCTION}

Bangka Belitung Islands Province is one of the provinces in Indonesia regarded as the center of white pepper production and the largest white pepper producing region. White pepper in the Bangka Belitung Islands Province is known as Muntok white pepper because it is a superior pepper product in Indonesia (BI, 2015). The name of Muntok white pepper is widely known since the Bangka Belitung Islands Province is the first center of production area to develop pepper in Indonesia (Permentan, 2012). Muntok white pepper has a good opportunity in the international market because it has been known since the ancient times with distinctive taste and aroma (BI, 2015). The development of the volume and export value of Muntok white pepper in the Bangka Belitung Islands Province can be seen in Figure 1. 


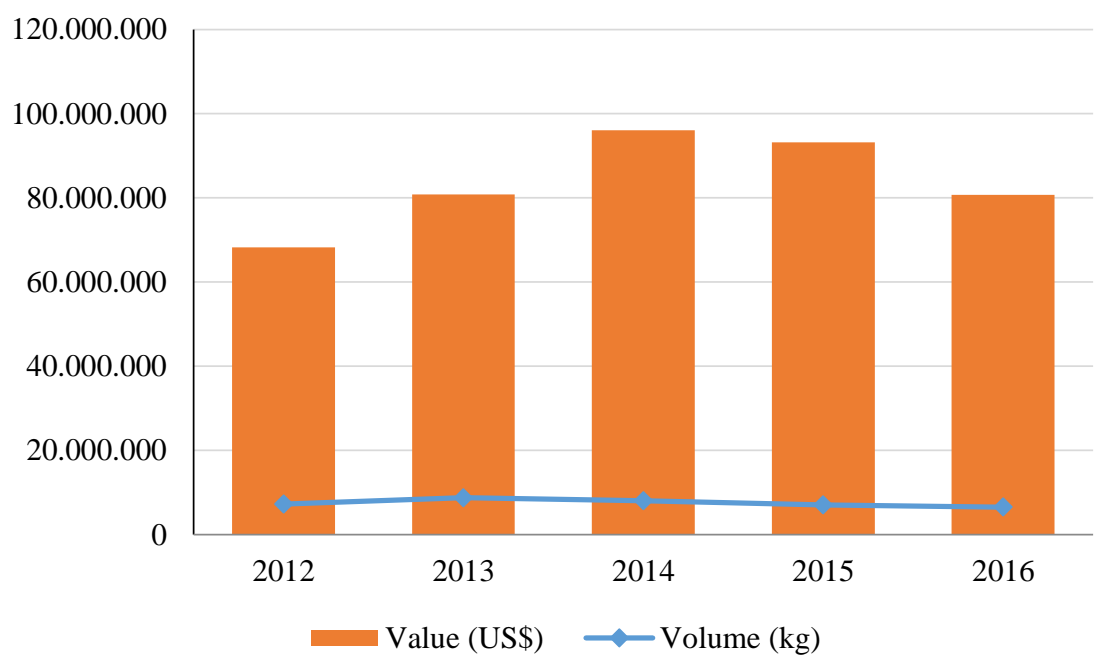

Source: BP3L (2017)

FIGURE 1. MUNTOK WHITE PEPPER EXPORT IN BANGKA BELITUNG PROVINCE, 2012-2016.

Figure 1 shows the development of Muntok white pepper exports in the Bangka Belitung Islands Province, both the volume and value of exports fluctuated. It can be seen from 2012 to 2014 the volume of white pepper exports increased. However, there was a decrease in the volume of white pepper from 2014 to 2016. According to Ginting (2004), fluctuations in the production and volume of pepper exports may happen due to problems with low prices and fluctuations so that it makes farmers uninterested to care for and increase pepper production.

White pepper marketing system in the Province of Bangka Belitung generally has a steady marketing flow in which farmers selling white pepper to village collector traders, then village collector traders selling white pepper to sub-district traders after the sub-district traders sell white pepper to traders major or exporters (BI, 2015).

Marketing is said to be efficient if price changes from one marketing institution are immediately transmitted to other marketing institutions in one marketing chain (Hall et al. 1981). Conversely, if changes in prices in a market such as falling prices at the farm level are transmitted slowly and not completely to consumers then this condition indicates less efficient in terms of price efficiency (Kohls \& Uhl, 2002).

The need for an efficient marketing system so that products are offered at reasonable prices and encourage producers to increase production (Omar et al. 2014). One measure used to analyze marketing efficiency in terms of price efficiency is price transmission (Meyer $\&$ von Cramon-Taubadel, 2004). Symmetry price transmission is measured by the relative response of prices in the downstream sector to the ups and downs of prices in the upstream sector (Miller \& Hayenga, 2001). Asymmetric price transmission is a condition in which a market responds to price increases and price decreases that occur in other markets differently (Bailey \& Brorsen, 1989).

Asymmetry price transmission can occur in slow price movement cycles (Miller \& Hayenga, 2001). In line with the statement of Vavra \& Goodwin (2005) that the transmission of prices between producers and consumers can run asymmetrically because of 
the uncompetitive behavior of traders, especially in a concentrated market. In a concentrated market, traders will try to maintain their welfare and profits by not continuing the rise and fall in prices according to the actual price signal. Traders are more likely to continue decreasing prices from consumers to producers compared to price increases.

The average price of white pepper in the producer market from January 2007 to December 2016 was IDR 72,531 per kg, in the exporter market at IDR 80,622 per kg, while in the world market it was IDR 99,017 per $\mathrm{kg}$. It showed that there was a high rate of disparity price between producers to exporters with score IDR 8,091 per kilogram, while between the exporters market and the world market which is IDR 18,395 per $\mathrm{kg}$. Conforti (2004) explains that the magnitude of price disparity in marketing chains can be caused by long marketing chains or abuse of market power owned by traders, causing margins formed in marketing from the upstream sector (producers) to the downstream sector (consumers) to be very large so that marketing become inefficient. The price of white pepper in Bangka Belitung Islands Province is presented in Figure 2.

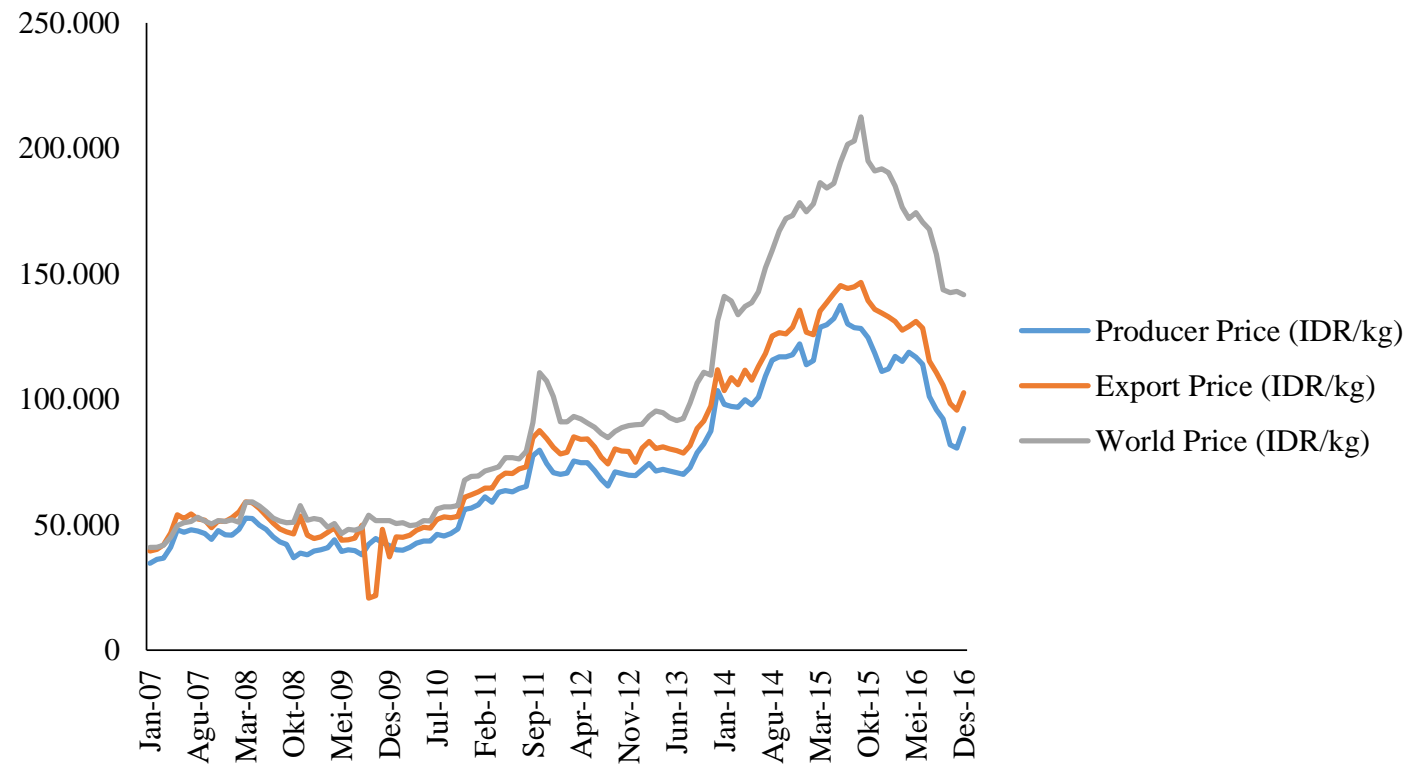

Source: IPC 2017

FIGURE 2. REAL PRICE MOVEMENT OF MUNTOK WHITE PEPPER IN PRODUCERS, EXPORTERS AND WORLD MARKETS JANUARY 2007 - DECEMBER 2016

Figure 2 shows fluctuations in the price of white pepper in the producer market, exporter market, and the world market. From 2007 to 2016, the pattern of white pepper price movements in the producer market, exporter market, and the world market tend to show the same pattern. However, at a particular month there was a different response on the price of white pepper between producer market to exporter market where by when the price at producers market went down, the price of white pepper at exporters market went up. Likewise, when the price of white pepper on the exporters market decreases, the price of white pepper on the world market increases. This condition allows that price changes in one marketing institution are transmitted imperfectly to another marketing institution or asymmetry. However, this is not enough to be able to say that the transmission of white 
pepper prices between producer markets, exporter markets, and the world market is asymmetrical. Therefore, statistical testing is needed regarding the transmission of the price of white pepper.

Research on the integration of the white pepper market has been widely carried out by previous researchers. For example, Djulin \& Malian (2005) analyzed the integration of the Indonesian black and white pepper market in the main production areas with the export market. Then Fazaria et al. (2016) analyzed the integration of the black pepper market and the Indonesian white pepper market with the international market. However, no previous studies have analyzed the transmission of white pepper prices, especially those that separate price increases and decreases. Thus, the study aims to analyze the transmission price of white pepper in the Bangka Belitung Province Island from the producer to the international trade. Balcombe, Bailey, \& Brooks, 2007; Cutts \& Kristen, 2006; Koutroumanidis et al. 2009; Miller \& Hayenga, 2001 in Sahara \& Wicaksena (2013) argued that the asymmetric price transmission was crucial to be conducted to provide information about the welfare of producers and consumers as well as about price efficiency at a marketing channel.

\section{RESEARCH METHOD}

The secondary data was used to obtain the price of white pepper in producer market, exporter market, and world market. The data used are monthly price data from January 2007 to December 2016, with 120 observations. The data was obtained from the International Pepper Community (IPC). The price variable used in this study was calculated by the Consumer Price Index (CPI). The use of CPI is done because of limitations in the availability of wholesale trade price index data.

Asymmetric Error Correction Model (AECM) was employed to analyse the price transmission of white pepper in Bangka Belitung Island Province using Eviews program. The AECM analysis consists of several stages which can be seen in the followings:

\section{Data Stationarity Test}

The first step that needs to be done is data stationarity testing to estimate a model that uses time series data. The analysis was applied to avoid the issue of spurious regression. Augmented Dickey-Fuller test was used to test the stationary data at the level or first difference. Firdaus (2011) stated that if the time series did not stationary or consisted of unit root on level, it required further test on first difference. The equation of augmented DickeyFuller test developed by Enders (1995) is stated as follow:

$$
\begin{aligned}
& \Delta y_{t}=\gamma y_{t-1}+\sum_{i=2}^{p} \beta_{i} \Delta y_{t-i+1}+\varepsilon_{t} \ldots .(1) \\
& \Delta y_{t}=a_{0}+y_{t-1}+\sum_{i=2}^{p} \beta_{i} \Delta y_{t-i+1}+\varepsilon_{t} \ldots .(2) \\
& \Delta y_{t}=a_{0}+\gamma_{t-1}+a_{2} t+\sum_{i=2}^{p} \beta_{i} \Delta y_{t-i+1}+\varepsilon_{t} \ldots .(3)
\end{aligned}
$$

$\Delta y_{t}$ is the first difference under test variable $\left(y_{t}-y_{t-1}\right) ; y$ is the variables tested for stationarity (Bangka Belitung Province white pepper prices in producer markets, exporter 
markets, and world markets); $t$ is period of time; $\gamma$ and a is the model coefficient; $p$ is lag length in the model; and $\varepsilon_{t}$ is residual.

Equation (1) is used for data that are assumed to have no intercepts and trends. Equation (2) is used for data that are assumed to only have intercepts and have no trends. Equation (3) is used for data that are assumed to have intercepts and trends. Hypothesis testing in the augmented Dickey-Fuller test are stated as follow:

$\mathrm{HO}: \gamma=0$ means the time series data are not stationary.

$\mathrm{H} 1: \gamma \neq 0$ means the time series data are stationary.

Hypotheses testing criteria:

If the actual ADF statistical value is less than the MacKinnon critical values at the actual level used then rejecting $\mathrm{HO}$ means the data stationer. Conversely, if the statistical ADF value is actually more than the MacKinnon critical values at the actual level used, then not rejecting $\mathrm{HO}$ means the data is not stationary.

\section{Determination of Optimal Lag}

Firdaus (2011) argued that the determination of long lag in Vector Autoregression (VAR) system was applied to show the reaction tome of a variable towards other variables and to eliminate the autocorrelation. Aryani (2012) stated that the determination of optimal long lag might use information such as Akaike Information Criterion (AIC), Schwarz Information Criterion (SC), Hannan-Quinn Criterion (HQ), Likelihood Ratio, and Final Prediction Error (FPE). Schwarz Information Criterion (SC) was utilized to understand the optimal long lag in the study, with the following formula:

$$
S I C(k)=T \ln \left(\frac{S S R(k)}{T}\right)+n \ln (T) \ldots .(4)
$$

From the formula, $T$ is the number of observations; $k$ is the lag length; SSR is Sum Squares Residual; and $n$ is the number of parameters estimated.

\section{Cointegration Test}

If the result of data stationary test on the level illustrated the unstationary data while the first difference showed otherwise, it required the cointegration test (Firdaus, 2011). It was used to investigate the long-term relationship amongst the price of a particular commodity in a region (Firdaus \& Gunawan, 2012). The cointegration test in this study uses the procedure of Johansen \& Juselius (1990), as implemented by Reziti \& Panagopoulos (2008), and Sahara \& Wicaksena (2013), with the formula stated as follows:

$$
\Delta P_{t}=c+\Pi P_{t-1}+\sum_{j=1}^{k-1} B_{j} \Delta P_{t-j}+\varepsilon_{t} \ldots
$$

From the formula $\Pi$ is a matrix of long-term parameters and adjustment parameters; $B_{j}$ is a short-term parameter matrix; $\varepsilon_{t}$ is a residual Gaussian vector; $j$ is the number of lags. After the cointegration test results were obtained, the trace test value and max eigenvalue were then compared with the critical value using the formula developed by Enders (1995) which is written as follows:

$$
\lambda_{\text {trace }}(r)=-T \sum_{i=r+1}^{n} \ln \left(1-\hat{\lambda}_{i}\right) \ldots
$$


From the formula, $\hat{\lambda}_{i}$ is the estimated value of the root characteristics (eigenvalues) selected from the estimated $\pi$ matrix; $T$ is the number of observations; and $r$ is the number of cointegration vectors. In the $\lambda_{\text {trace }}$ test, the null hypothesis is that the number of cointegration vectors is less than or equal to $r$ as a general alternative. In the $\lambda_{\max }$ test, the null hypothesis is that the number of cointegration vectors is equal to $r$ as an alternative to the cointegration vector $r+1$ (Enders 1995).

\section{Causality Test}

Causality testing was carried out after the cointegration testing had been done. Causality test was applied to examine the relationship way between two trading market. According to Acquah \& Onumah (2010), this causality test is carried out to determine the direction of price transmission. The direction of white pepper transmission prices among producer markets, exporter markets, and world markets was determined by using the Engle and Granger Causality test. According to Sahara \& Wicaksena (2013) that the Engle and Granger causality test is used to investigate the causality relationship between prices at producer level and prices at the consumer level. Causality test in this study follows the application of Reziti \& Panagopoulos (2008), Koutroumanidis et al. (2009), and Sahara \& Wicaksena (2013) based on the methodology proposed by Engle and Granger (1987), with the formula stated as follow:

$$
\begin{aligned}
& \Delta P j_{t}=\mu_{1}+\sum_{i=1}^{n_{1}} \beta_{p j} \Delta P j_{t-i}+\sum_{i=0}^{n_{2}} \beta_{p k} \Delta P k_{t-i}+\pi_{1} Z_{t 1-1}+e_{t 1} \ldots .(8) \\
& \Delta P k_{t}=\mu_{2}+\sum_{i=1}^{n_{1}} \beta_{p k} \Delta P k_{t-i}+\sum_{i=0}^{n_{2}} \beta_{p j} \Delta P j_{t-i}+\pi_{2} Z_{t 2-1}+e_{t 2} \ldots .(9)
\end{aligned}
$$

$P j_{t}$ is the price of white pepper on the ke-j market (IDR/kg); $P k_{t}$ is the price of white pepper on the ke-k market (IDR/kg); and $e$ is residual. The Rules of decision are stated below:

a. $\pi_{1} \neq 0, \pi_{2} \neq 0$ means there is a long-term relationship between the two variables that are reciprocal.

b. $\pi_{1}=0, \pi_{2} \neq 0$ means the long-term $\mathrm{Pj}_{\mathrm{t}}$ causes $\mathrm{Pk}_{\mathrm{t}}$.

c. $\pi_{1} \neq 0, \pi_{2}=0$ means $P k_{t}$ in the long run causes $P j_{t}$.

\section{Estimation of the AECM Model}

The transmission of white pepper prices in the Bangka Belitung Islands Province among the producer markets, exporter markets, and world markets was estimated using the Asymmetric Error Correction Model developed by Von Cramon-Taubadel \& Loy (1996), with the form of the equation stated below:

$$
\Delta P j_{t}=\mu_{1}+\sum_{i=1}^{n} \beta_{1}^{-} \Delta P j_{t-i}^{-}+\sum_{i=0}^{n} \beta_{2}^{-} \Delta P k_{t-i}^{-}+\pi^{-} Z_{t-1}^{-}+\sum_{i=1}^{n} \beta_{1}^{+} \Delta P j_{t-i}^{+}+\sum_{i=0}^{n} \beta_{2}^{+} \Delta P k_{t-i}^{+}+\pi^{+} Z_{t-l}^{+}+\varepsilon_{t} . .(10)
$$

From the formula, $P j_{t}$ is the price of white pepper in the ke-j market (IDR/kg)); $P k_{t}$ is the price of white pepper in the $\mathrm{k}-\mathrm{market}(\mathrm{IDR} / \mathrm{kg}) ; Z_{\mathrm{t} 1}$ is the error correction term which is the residual lag of the long-term equilibrium equation; $\varepsilon_{t}$ is residual; and $n$ is the lag length. 
A positive sign $(+)$ represents a price increase and a negative sign $(-)$ describes a price decline. $\mathrm{ECT}^{+}$is an adjustment of the price of white pepper in the j-market to the change in price of white pepper in the ke-k market when the price deviation is above balance. ECT is the adjustment of the price of white pepper in the ke-j market to the change in price of white pepper in the ke-k market when the price deviation is below balance.

\section{Wald Test}

The test used to determine whether price transmission is running symmetrically or asymmetrically will be statistically proven using the Wald test (Reziti \& Panagopoulos, 2008). Hypothesis testing in the Wald test is described as follow:

\section{Short Term}

$$
\begin{aligned}
& H_{0}: \sum_{i=0}^{n} \beta_{2}^{-}=\sum_{i=0}^{n} \beta_{2}^{+} \\
& H_{1}: \sum_{i=0}^{n} \beta_{2}^{-} \neq \sum_{i=0}^{n} \beta_{2}^{+}
\end{aligned}
$$

The formula describe if the Wald test results show that $\mathrm{H}_{0}$ is not rejected, this means that the transmission of the price of white pepper in the short run runs symmetry. If the Wald test results show reject $\mathrm{H}_{0}$, it means that the transmission of the price of white pepper in the short run runs asymmetry.

\section{Long Term}

$$
\begin{aligned}
& H_{0}: \pi^{-}=\pi^{+} \\
& H_{1}: \pi^{-} \neq \pi^{+}
\end{aligned}
$$

The formula above describe if the Wald test results show that $\mathrm{H}_{0}$ is not rejected, this means that the transmission of the price of white pepper in the long run runs symmetry. If the Wald test results show reject $\mathrm{H}_{0}$, it means that the transmission of the price of white pepper in the long run runs asymmetry.

\section{RESULT AND DISCUSSIONS}

Analysis of the transmission of white pepper prices in the Bangka Belitung Islands Province among producer markets, exporter markets, and the world market is carried out through several stages of analysis:

\section{Data Stationarity Test}

The first step carried out in analyzing the transmission of white pepper prices in the Bangka Belitung Islands Province is testing the stationarity of data consisting of white pepper price data on producer markets, exporter markets, and world markets. The following table 1 presents the results of the stationary test results for white pepper prices in the Bangka Belitung Islands Province.

TABLE 1. STATIONERITY TEST RESULTS FOR WHITE PEPPER PRICE DATA IN BANGKA BELITUNG ISLANDS PROVINCE

\begin{tabular}{ccccccc}
\hline Variable & ADF & None Intercept and Trend & ADF & Intercept & ADF & Intercept \\
& t-stat & & t-stat & & t-stat & and Trend \\
\hline
\end{tabular}




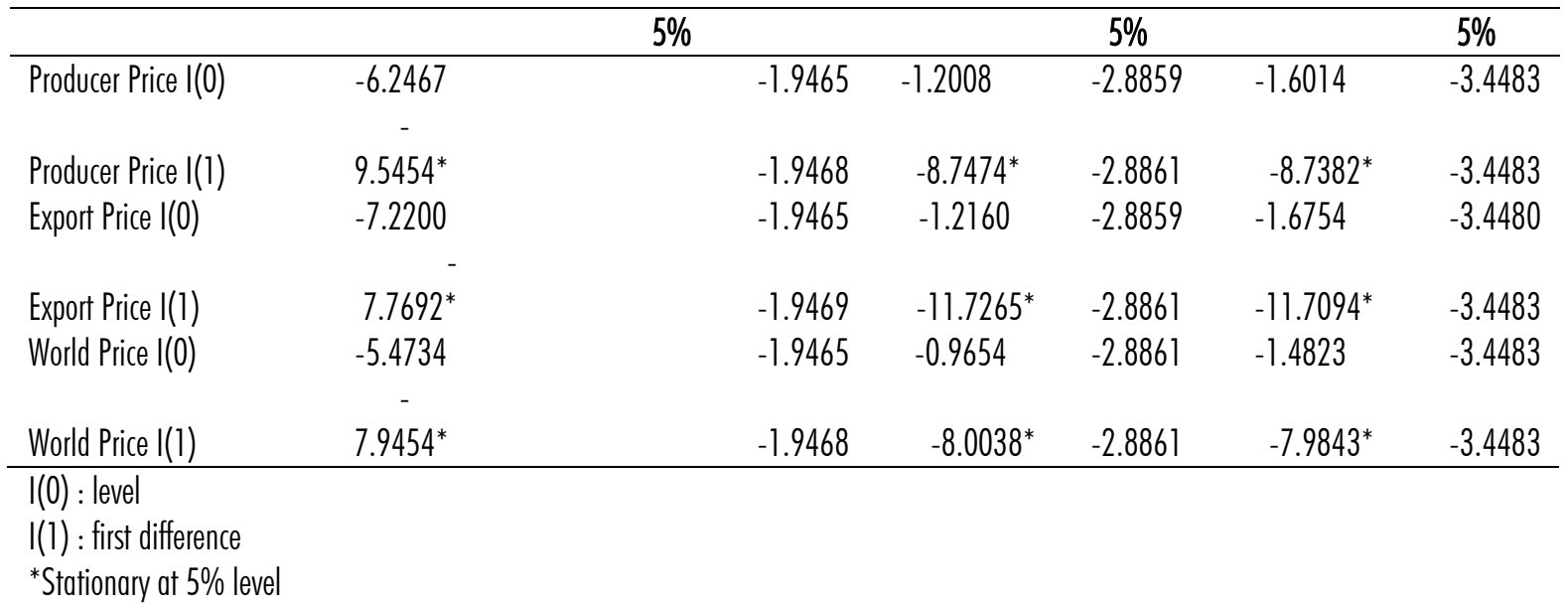

The data stationary test in the study was applied at level first difference not only among none intercept and trend, with intercept, but also with intercept and trend. As the result of data stationary test at level illustrated all the white pepper price on producer market, exporter market, and world market with the unstationary data, the data stationary test on first difference. Was conducted after being tested on the data stationary test on the first difference, the results showed that all of the price data indicated stationary (Table 1). Therefore, the cointegration analysis method can be continued. Firdaus (2011) explained that if the result of data stationary test showed the unstationary data on level, the data was considered as stationary at first difference, then cointegration testing is necessary.

\section{Determination of Optimal Lag Length}

This study uses the Schwarz Information Criterion (SC) to determine the optimal lag length. The results of calculations using SC obtained the optimum lag that is lag 1 on the relationship between prices in producer markets and exporter markets, producer markets and world markets, as well as exporter and world markets. Therefore, the optimal lag used in the white pepper price transmission model is lag 1 . This means that all variables in the model affect each other not only in the current period, but also related to the previous 1 month.

\section{Cointegration Test}

The results of the stationarity test show that the data is not stationary at the level but stationer at the first difference, so cointegration testing is necessary. Johansen's cointegration test results used to determine the number of equations in the cointegrated model can be seen in Table 2.

Table 2 shows that the results of the cointegration test at none obtained a trace statistic value of more than critical value at the $5 \%$ real level which means that it was significant at the $5 \%$ real level. Therefore, from the results of the cointegration test giving significant results in none, it means that in the equation system there is 1 cointegrated equation. This means that the price of white pepper on the producer market, the exporter market, and the world market has a long-term equilibrium relationship. This is in line with the results of research by Fazaria et al. (2016). However, the cointegration relationship does 
not suffice to show that the white pepper market in each of these markets is perfectly integrated. Therefore, it is necessary to further analyze the transmission of prices by using the Asymmetric Error Correction Model to find out how white pepper prices respond to a market to changes in prices in other markets.

TABLE 2. COINTEGRATION TEST RESULTS

\begin{tabular}{llrrrr}
\hline \multicolumn{1}{c}{ Market } & Number of Cointegration Equations & Eigenvalue & Trace Statistic & Critical Value & Prob. \\
\hline Producer and Export & None & & & & \\
Market & At Most l & 0.2736 & 37.9761 & 12.3209 & 0.0000 \\
Producer and World & None & 0.0022 & 0.2579 & 4.1299 & 0.6712 \\
Market & At Most l & 0.1772 & 25.5302 & 20.2618 & 0.0085 \\
Export and World Market & None & 0.0211 & 2.5184 & 9.1645 & 0.6739 \\
& At Most l & 0.1663 & 24.1853 & 20.2618 & 0.0137 \\
& & 0.0228 & 2.7219 & 9.1645 & 0.6338 \\
\hline
\end{tabular}

${ }^{* *}$ Significant at the $5 \%$ level

\section{Causality Test}

The causality test used in this study is the Granger causality test. This causality test is carried out to determine the direction of the relationship between the white pepper market in the producer market, the exporter market, and the world market. This means that the Granger causality test is used to determine the direction of price transmission, ie whether the formation of white pepper prices in one market is influenced by the price of white pepper in other markets. The following table 3 presents the results of causality test data on white pepper prices in the Bangka Belitung Islands Province.

TABLE 3. CAUSALITY TEST RESULTS FOR WHITE PEPPER PRICE DATA IN BANGKA BELITUNG ISLANDS PROVINCE

\begin{tabular}{lllrl}
\hline & & \multicolumn{1}{c}{ Relation } & F-statistic & Prob. \\
\hline Producer Price & $\longrightarrow$ & Export Price & 29.3468 & $3 . \mathrm{E}-07^{*}$ \\
Export Price & $\longrightarrow$ & Producer Price & 0.0188 & 0,8911 \\
Producer price & $\longrightarrow$ & World Price & 32.7990 & $8 . \mathrm{E}-08^{*}$ \\
World Price & $\longrightarrow$ & Producer Price & 0.7675 & 0.3828 \\
Export Price & $\longrightarrow$ & World Price & 17.3625 & $0.0500^{* *}$ \\
World Price & $\longrightarrow$ & Export Price & 3.9214 & $06 . \mathrm{E}-$ \\
& & & & $058^{*}$ \\
\hline
\end{tabular}

*Significant at the $1 \%$ level

${ }^{* *}$ Significant at the $5 \%$ level

Based on Table 3, the causality relationship between the price of white pepper in the Bangka Belitung Islands Province in the producer market and the exporter market shows a one-way relationship, namely the price of white pepper in the producer market influences the price of white pepper in the exporter market, whereas the price of white pepper in the exporter market does not affect the price white pepper on the producer market. The results of this study are in line with the results of Djulin \& Malian (2005) research that the price of white pepper formed in farmers is not determined by the price at the exporter level.

In addition, the results of causality test between the price of white pepper on the producer market and the world market also showed a one-way relationship, namely the price of white pepper on the producer market affects the price of white pepper on the world 
market, but the price of white pepper on the world market does not affect the price of white pepper on the market producer.

The causality relationship between the price of white pepper on the exporter market and the world market shows a two-way relationship, the price of white pepper on the exporter market affects the price of white pepper on the world market, whereas the price of white pepper on the world market affects the price of white pepper on the exporter market. This is in line with the results of research by Fazaria et al. (2016) that between the price of white pepper in the export market and in the spot market has a two-way causality relationship. According to them, this condition occurs because the effect of supply of white pepper originating from the export market has relatively similar power to the effect of demand for white pepper originating from the spot market, so that the price formation that occurs in the two markets affects each other.

\section{Estimated AECM}

After the causality test, the next step is to estimate the model on the short-term and long-term relationship between the price of white pepper on the producer market, the exporter market, and the world market. The AECM estimation results can be seen in Table 4.

TABLE 4. ESTIMATED AECM RESULTS

\begin{tabular}{|c|c|c|c|c|c|c|c|}
\hline Voriable & $\mathrm{HP} \rightarrow \mathrm{HE}$ & Variable & $H P \rightarrow H D$ & Variable & $\mathrm{HE} \rightarrow \mathrm{HD}$ & Variable & $\mathrm{HD} \rightarrow \mathrm{HE}$ \\
\hline Intercept & $\begin{array}{l}1032.856 \\
(1.8480)\end{array}$ & Intercept & $\begin{array}{l}-1406.470 \\
(-2.2373)\end{array}$ & Intercept & $\begin{array}{c}-1265.113 \\
(-1.9122)\end{array}$ & Intercept & $\begin{array}{l}883.6866 \\
(1.2151)\end{array}$ \\
\hline$\Delta \mathrm{HE}_{t-1}^{+}$ & $\begin{array}{c}-0.500^{*} \\
(-4.4003)\end{array}$ & $\Delta H D_{t-1}^{+}$ & $\begin{array}{c}-0.0543 \\
(-0.4388)\end{array}$ & $\Delta \mathrm{HD}_{t-1}^{+}$ & $\begin{array}{c}0.0841 \\
(0.7864)\end{array}$ & $\Delta \mathrm{HE}_{t-1}^{+}$ & $\begin{array}{l}-0.5200^{*} \\
(-3.8591)\end{array}$ \\
\hline$\Delta \mathrm{HE}_{t-1}^{-}$ & $\begin{array}{l}0.6135^{*} \\
(4.8356)\end{array}$ & $\Delta \mathrm{HD}_{t-1}^{-}$ & $\begin{array}{l}0.2118 \\
(1.5174)\end{array}$ & $\Delta H D_{t-1}^{-}$ & $\begin{array}{c}0.2272 \\
(1.6071)\end{array}$ & $\Delta \mathrm{HE}_{t-1}^{-}$ & $\begin{array}{l}0.5413^{*} \\
(3.3839)\end{array}$ \\
\hline$\Delta \mathrm{HP}_{t}^{+}$ & $\begin{array}{l}0.8313^{*} \\
(6.9902)\end{array}$ & $\Delta \mathrm{HP}_{t}^{+}$ & $\begin{array}{l}0.9341^{*} \\
(7.5533)\end{array}$ & $\Delta \mathrm{HE}_{t}^{+}$ & $\begin{array}{l}0.8154^{*} \\
(6.9586)\end{array}$ & $\Delta \mathrm{HD}_{t}^{+}$ & $\begin{array}{l}0.5821^{*} \\
(4.5952)\end{array}$ \\
\hline$\triangle \mathrm{HP}_{t}^{-}$ & $\begin{array}{l}0.7675^{*} \\
(5.0303)\end{array}$ & $\Delta \mathrm{HP}_{t}^{-}$ & $\begin{array}{c}0.2047 \\
(1.1872)\end{array}$ & $\Delta \mathrm{HE}_{t}^{-}$ & $\begin{array}{c}0.1864 \\
(1.6869)\end{array}$ & $\Delta \mathrm{HD}_{t}^{-}$ & $\begin{array}{l}0.5988^{*} \\
(3.6185)\end{array}$ \\
\hline$\Delta \mathrm{HP}_{t-1}^{+}$ & $\begin{array}{c}0.1626 \\
(1.0635)\end{array}$ & $\Delta \mathrm{HP}_{t-1}^{+}$ & $\begin{array}{c}0.3350 \\
(1.7901)\end{array}$ & $\Delta \mathrm{HE}_{t-1}^{+}$ & $\begin{array}{l}0.2693^{* *} \\
(2.2297)\end{array}$ & $\Delta \mathrm{HD}_{t-1}^{+}$ & $\begin{array}{l}-0.0127 \\
(-0.0991)\end{array}$ \\
\hline$\Delta \mathrm{HP}_{t-1}^{-}$ & $\begin{array}{l}-0.6689 * \\
(-3.4805)\end{array}$ & $\Delta \mathrm{HP}_{t-1}^{-}$ & $\begin{array}{l}-0.3689^{*} \\
(-2.0086)\end{array}$ & $\Delta \mathrm{HE}_{t-1}^{-}$ & $\begin{array}{l}-0.3648^{* *} \\
(-2.5018)\end{array}$ & $\Delta \mathrm{HD}_{t-1}^{-}$ & $\begin{array}{c}0.0736 \\
(0.4312)\end{array}$ \\
\hline $\mathrm{ECT}{ }_{t-1}^{+}$ & $\begin{array}{l}-0.8544^{*} \\
(-4.9847)\end{array}$ & $\mathrm{ECT}{ }_{t-1}^{+}$ & $\begin{array}{l}-0.2161^{*} \\
(-3.3757)\end{array}$ & $\mathrm{ECT}_{t-1}^{+}$ & $\begin{array}{l}-0.3684^{*} \\
(-4.6400)\end{array}$ & $\mathrm{ECT}{ }_{t-1}^{+}$ & $\begin{array}{l}-0.0636 \\
(-0.3430)\end{array}$ \\
\hline $\mathrm{ECT}{ }_{t-1}^{-}$ & $\begin{array}{l}-0.7743^{*} \\
(-7.2533)\end{array}$ & $\mathrm{EC} \mathrm{C}_{t-1}^{-}$ & $\begin{array}{l}-0.2934^{*} \\
(-2.8963)\end{array}$ & $\mathrm{ECT}{ }_{t-1}^{-}$ & $\begin{array}{l}-0.2539^{* *} \\
(-2.5810)\end{array}$ & $\mathrm{ECT}_{t-1}^{-}$ & $\begin{array}{l}-0.6693^{*} \\
(-5.3981)\end{array}$ \\
\hline $2^{2}$ & 0.6664 & $\mathrm{R}^{2}$ & 0.5765 & $R^{2}$ & 0,5085 & $R^{2}$ & 0.4400 \\
\hline $2^{2}$-adj & 0,6420 & $R^{2}$-adj & 0.5454 & $R^{2}$-adj & 0,4725 & $R^{2}-a d j$ & 0.3989 \\
\hline -statistic & 27,2221 & F-statistic & 18.5466 & F-statistic & 14,0987 & F-statistic & 10.7039 \\
\hline WW-stat & 1,7349 & DW-stat & 1.8784 & DW-stat & 1,8640 & DW-stat & 1.8392 \\
\hline
\end{tabular}

* Significant at 1\% level

** Significant at 5\% level

$\mathrm{HP}=$ Price in the producer market

$\mathrm{HE}=$ Price in the exporter market

$\mathrm{HD}=$ Prices on the world market 
Based on Table 4, the transmission of white pepper prices from the producer market to the exporter market in the short run shows that in the period $t$, the increase and decrease in the price of white pepper in the producer market will be responded to by the exporter market. Then in the previous period $(\mathrm{t}-1)$, there was a difference in the response by the exporter market to changes in the price of white pepper in the producer market. This means that the increase in the price of white pepper in the producer market in the previous period $(t-1)$ does not affect the determination of the price of white pepper in the exporter market. Conversely, when the decline in the price of white pepper in the producer market is responded to by the price increase by the exporter market. This condition indicates that in the short term the transmission of the price of white pepper from the producer market to the exporter market runs asymmetry. Conversely, if seen from the significance and sign of the positive ECT coefficient and negative ECT, it indicates that in the long run the transmission of white pepper prices from the producer market to the exporter market runs symmetry.

Transmission of the price of white pepper from the producer market to the world market in the short term shows that the increase in the price of white pepper on the producer market in the $t$ period will be responded to by the world market by raising prices. However, the decline in the price of white pepper on the producer market in the t period did not affect the price of white pepper on the world market. Meanwhile in the previous period ( $t-1)$, the decline in the price of white pepper on the producer market will be responded to by the world market by raising prices. This indicates that in the short term transmission of asymmetric prices from producer markets to world markets. If seen from the significance and signs of positive ECT coefficients and negative ECT, in the long run the transmission of white pepper prices from producer markets to world markets indicates symmetry.

Transmission of the price of white pepper from the exporter market to the world market in the short term shows that in the $t$ period, the increase in the price of white pepper on the exporter market will be responded to by the world market by raising prices, while the decline in the price of white pepper on the exporter market does not affect the price of white pepper in the world market. In the previous period $(\mathrm{t}-1)$, an increase in the price of white pepper on the exporters market would be responded to by an increase in prices by the world market. Conversely, a decrease in the price of white pepper on the exporters market in the previous period ( $t-1)$, will be responded by world markets by raising prices. This condition indicates that in the short term the transmission of the price of white pepper from the exporter market to the world market runs asymmetry. On the contrary, in the long run, there is a symmetry of price transmission because when viewed from the significance and signs the positive ECT coefficient and negative ECT indicate symmetry.

Furthermore, the transmission model of white pepper prices from the world market to the exporter market in the short term shows that in the $t$ period, the increase and decrease in the price of white pepper on the world market will be responded to by the exporter market with an increase and decrease in prices or responded in the same direction. 
However, in the long run it indicates asymmetry because if it is seen from the positive ECT coefficient it is not significant, meaning that in the long run the decline in the price of white pepper on the world market does not affect the price of white pepper on the exporter market. On the other hand, the negative ECT coefficient has a significant value of $-0,6693$ which means that when there is a price deviation below the equilibrium ie when the price of white pepper on the exporter market does not go up when the price of white pepper on the world market has increased, but after about 8 months the price of white pepper on the exporter market will adjust up when the price of white pepper on the world market increases. The results of this study are in line with the results of research by Djulin \& Malian (2005) that an increase in the price of white pepper on the world market will be responded to slowly by exporters.

\section{Wald Test}

The next step in the analysis of price transmission is to carry out the Wald test. This test is conducted to prove whether the coefficient of positive shock and negative shock both in the short and long term are identical or different. If the results show a statistically significant difference (reject $\mathrm{H}_{0}$ ), then the transmission of prices from one market to another is asymmetrical. Full Wald test results can be seen in Table 5 .

TABLE 5. WALD TEST RESULIS

\begin{tabular}{|c|c|c|c|}
\hline Direction & Wald test & F-statistic & Probility \\
\hline \multirow[t]{3}{*}{ Producer Price $\longrightarrow$ Export Price } & $\mathrm{H}_{0}: \Delta \mathrm{HP}_{\dagger}^{-}=\Delta \mathrm{HP}_{\dagger}^{+}$ & 0.0837 & 0.7729 \\
\hline & $\mathrm{H}_{0}: \Delta \mathrm{HP}_{\mathrm{t}-\mathrm{l}}^{-}=\Delta \mathrm{HP}^{+}{ }_{\mathrm{t}-\mathrm{l}}$ & 10.2239 & $0.0018^{*}$ \\
\hline & $\mathrm{H}_{0}: \mathrm{ECT}_{t-1}^{+}=\mathrm{ECT}_{t-1}^{-}$ & 0.1491 & 0.7001 \\
\hline \multirow[t]{3}{*}{ Producer Price $\longrightarrow$ World Price } & $H_{0}: \Delta H P_{+}^{-}=\Delta H P^{+}{ }_{t}$ & 9.3541 & $0.0028^{*}$ \\
\hline & $H_{0}: \Delta H P_{t-1}^{-}=\Delta H P^{+}{ }_{t-1}$ & 6.0368 & $0.0156^{* *}$ \\
\hline & $\mathrm{H}_{0}: \mathrm{ET}_{t-1}^{+}=\mathrm{ECT}_{t-1}^{-}$ & 0.3174 & 0.5743 \\
\hline \multirow[t]{2}{*}{ Export Price $\longrightarrow$ World Price } & $\begin{array}{l}H_{0}: \Delta H E_{\dagger}=\Delta H E^{+} \\
H_{0}: \Delta H E_{+-1}^{-}=\Delta H E^{+}{ }_{t-1}\end{array}$ & $\begin{array}{r}12.0454 \\
9.8402\end{array}$ & $\begin{array}{l}0.0007^{*} \\
0.0022^{*}\end{array}$ \\
\hline & $\mathrm{H}_{0}: \mathrm{ECT}_{t-1}^{+}=\mathrm{ECT}_{t-1}^{-}$ & 0.6334 & 0.4279 \\
\hline \multirow[t]{2}{*}{ World Price $\longrightarrow$ Export Price } & $\begin{array}{l}H_{0}: \Delta H D_{\dagger}=\Delta H D^{+}{ }_{t} \\
H_{0}: \Delta H D_{t-1}^{-}=\Delta H D^{+}{ }_{t-1}\end{array}$ & $\begin{array}{l}0.0053 \\
0.1322\end{array}$ & $\begin{array}{l}0.9420 \\
0.7169\end{array}$ \\
\hline & $\mathrm{H}_{0}: \mathrm{ETT}_{t-1}^{+}=\mathrm{ECT}_{t-1}^{-}$ & 5.8890 & $0.0169^{* *}$ \\
\hline
\end{tabular}

${ }^{*}$ Significant at $1 \%$ level

Wald test results in Table 5 show that in the short term between positive shock and negative shock are statistically significantly different. This condition shows that there is a difference in the response of both the price of white pepper in the exporter market to changes in the price of white pepper in the producer market, the response of the price of white pepper in the world market to changes in the price of white pepper in the producer market, and the response of the price of white pepper in the world market to price changes white pepper on the exporter market. This can be seen from the Wald test results, in the period $t$ and the previous period $(t-1)$, the increase and decrease in the price of white pepper 
has a significant probability value. This means that in the short term the transmission of white pepper prices from the producer market to the exporter market, from the producer market to the world market, and from the exporter market to the world market runs asymmetrically or in other words in the short term the marketing system is not efficient in terms of price efficiency.

According to Vavra \& Goodwin (2005) that there is no transmission of symmetry prices between one market and other markets due to uncompetitive behavior from traders, especially in concentrated markets. In a concentrated market, traders do not continue to increase or decrease prices according to the actual price signal to maintain their welfare and profits. This is also reinforced by the statement of Djulin \& Malian (2005) that the white pepper market at the level of integrated farmers and exporters is very weak. This is because the determination of the price of white pepper at the farm level is not determined by the price of white pepper at the exporter level, but rather by village traders or collectors. Weak farmers' bargaining position in the decision to determine the price of white pepper due to the unavailability of sufficient price information that causes farmers to accept whatever the price set by the traders. Fazaria et al. (2016) explained that imperfect price transmission in the white pepper market could be caused by the presence of market power in the white pepper trade.

On the other hand, in the transmission model of white pepper prices from the producer market to the exporter market, from the producer market to the world market, and from the exporter market to the world market it is found that the coefficient of positive ECT and negative ECT indicates insignificant values. Therefore, it can be said that in the long run the transmission of white pepper prices from the producer market to the exporter market, from the producer market to the world market, and from the exporter market to the world market runs symmetry or in other words in the long run the marketing system is already efficient from in terms of price efficiency.

Unlike the case with the Wald test results on the transmission model of white pepper prices from the world market to the exporter market which shows that in the short run between positive shock and negative shock are not statistically significant meaning there is no difference in the response of white pepper prices in the exporter market to changes in pepper prices white on the world market. Conversely, if seen from the positive ECT coefficient and negative ECT shows a significant value so that it can be said that in the long run the transmission of white pepper prices from the world market to the exporter market runs asymmetrically. Thus, it can be said that in the long run the marketing system has not been efficient in terms of price efficiency.

\section{CONCLUSIONS}

The price transmission of white pepper in the province from producer market to exporter market, from producer market to world market, and from exporter market to world market figured that in the short-run applied asymmetrically while in the long-run implemented symmetrically. On the other hand, the transmission of white pepper prices 
from the world market to the exporter market runs symmetrically in the short period but in the long period it runs asymmetrically. The pepper association in the Bangka Belitung Islands Province provides information on the price of white pepper that is easily accessed by farmers. In addition, farmers still have a weak bargaining position in the decision to determine the selling price of white pepper so farmers should sell collectively, for example by forming groups in marketing white pepper to improve their bargaining position.

\section{ACKNOWLEDGEMENTS}

We send our big thanks to Universitas Bangka Belitung for providing the funding and the Institute of Research and Community Service (LPPM) at the University for supporting this research. We also thank BP3L for providing data related to white pepper.

\section{REFERENCES}

Acquah, H.G., Onumah, E.E. (2010). A comparison of the Different Approaches to Detecting Asymmetry in Retail-Wholesale Price Transmission. American-Eurasian Journal of Scientific Research 5(1):60-66. http://www.idosi.org/aejsr/5(1)10/9.pdf.

Aryani, D. (2012). Integrasi Vertikal Pasar Produsen Gabah dengan Pasar Ritel Beras di Indonesia. Jurnal Manajemen Teknologi, 11(2), 225-238. https://media.neliti.com/media/publications/113714-ID-none.pdf.

Bailey, D.V., \& Brorsen, B.W. (1989). Price Asymmetry in Spatial Fed Cattle Markets. Western Journal of Agricultural Economics, 14(2), 246-252. http://ageconsearch.umn.edu/bitstream/32352/1/14020246.pdf.

Balcombe, K., Bailey, A., \& Brooks, J. (2007). Threshold Effect in Price Transmission: the Case of Brazilian Wheat, Maize, and Soya Prices. American Journal of Agricultural Economics, 89(2), 308-323. https://www.jstor.org/stable/4492813.

BI. (2015). Kajian Model Pembiayaan dan Komoditas Lada Di Provinsi Kepulauan Bangka Belitung. Provinsi Kepulauan Babel: Bank Indonesia.

BP3L. (2017). Realisasi Ekspor Lada Putih (Muntok White Pepper). Provinsi Kepulauan Bangka Belitung: BP3L.

Cutts, M., \& Kristen, J. (2006). Asymmetric Prices Transmission and Market Concentration: an Investigation Into Four South African Agro-food Industries. South African Journal of Economics, 74(2), 323-333 https://onlinelibrary.wiley.com/doi/pdf/10.1111/j.1813-6982.2006.00064.x.

Conforti, P. (2004). Price Transmission in Selected Agricultural Markets. working paper FAO commoditiy and trade policy research, No 7, March, 2004. http://www.fao.org/tempref/docrep/fao/006/ad766e/ad766e00.pdf.

Djulin, A., Malian, H. (2005). Struktur dan Iintegrasi Pasar Ekspor Lada Hitam dan Lada Putih di Daerah Produksi Utama. Jurnal Sosio-Ekonomi Pertanian Soca 5(1):16-20. https://ojs.unud.ac.id/index.php/soca/article/view/4075.

Enders, W. (1995). Applied Econometric Time Series. New York: John Willey and Sons, Inc. 
Engle RF, Granger CWJ. 1987. Co-integration and error correction: representation, estimation, and testing. Econometrica. 55(1): 251-276. http://www.ntuzov.com/Nik_Site/Niks_files/Research/papers/stat_arb/EG_1987. pdf.

Fazaria, D.A., Hakim, D.B., \& Sahara. (2016). Analisis Integrasi Harga Lada di Pasar Domestik dan Internasional. Buletin Ilmiah Litbang Perdagangan, 10(2), 225-242. http://jurnal.kemendag.go.id/index.php/bilp/article/view/55.

Firdaus, M. (2011). Aplikasi Ekonometrika untuk Data Panel dan Time Series. Kampus IPB Taman Kencana Bogor: IPB Press.

Firdaus, M., \& Gunawan, I. (2012). Integration Among Regional Vegetable Markets In Indonesia. J. ISSAAS, 18(2), 96-106. http://www.issaas.org/journal/v18/02/journalissaas-v18n2-10-firdaus.pdf.

Ginting, K.H. (2014). Analisis Posisi Lada Putih Indonesia di Pasar Lada Putih Dunia. Institut Pertanian Bogor. http://repository.ipb.ac.id/handle/123456789/68354.

Hall, L.L., Tomek, W.G., Ruther, N.L., Kyereme, S.S. (1981). Case Studies in the Transmission of Farm Prices. New York: Cornell University. http://ageconsearch.umn.edu/record/181826.

IPC. (2017). Pepper Statistical Yearbook 2007-2016. Jakarta (ID): International Pepper Community.

Johansen, S., \& Juselius K. (1990). Maximum Likelihood Estimation adn Inference on Cointegration-With Appliactions to the Demand For Money. Oxford Bulletin of $\begin{array}{llr}\text { Economics and } & \text { 52(2), } & \text { 169-210. }\end{array}$ https://onlinelibrary.wiley.com/doi/epdf/10.1111/j.14680084.1990.mp52002003.x.

Kohls, R.L., Uhl, J.N. (2002). Marketing of Agricultural Products, Ninth Edition. New Jersey: Prentice Hall, Inc.

Koutroumanidis, T., Zafeiriou, E., \& Arabatzis, G. (2009). Asymmetry in Price Transmission Between the Producer and the Consumer Prices in the Wood Sector and the Role of Imports: the Case of Greece. Forest Policy and Economics, 11, 56-64. https://www.sciencedirect.com/science/article/abs/pii/S1389934108000798.

Meyer, J., von Cramon-Taubadel, S. (2004). Asymmetric Price Transmission: A Survey. Journal of Agricultural Economics 55(3):581-611. http://ageconsearch.umn.edu/bitstream/24822/1/cp02me91.pdf.

Miller, D.J., \& Hayenga, M.L. (2001). Price Cycles and Asymmetric Price Transmission In The US Pork Market. American Journal of Agricultural Economics, 83(3), 551-562. https://www.jstor.org/stable/1245086.

Omar, M.I., Islam, A., Hoq, M.S., Dewan, M.F., Islam, M.T. (2014). Marketing System and Market Integration of Different Egg Markets in Bangladesh. IOSR Journal of Business and Management 16(1):52-58. http://www.iosrjournals.org/iosr$\mathrm{jbm} /$ papers/Vol16-issue1/Version-1/H016115258.pdf.

Permentan. (2012). Pedoman Penanganan Pascapanen Lada. Jakarta (ID): Kementerian Pertanian. 
Reziti I, Panagopoulos Y. 2008. Asymmetric price transmission in the Greek agri-food sector: some tests. Agribusiness. 24(1):16-30. https://onlinelibrary.wiley.com/doi/epdf/10.1002/agr.20144.

Sahara., \& Wicaksena, B. (2013). Asymmetry in Farm-Retail Price Transmission: The Case of Chili Industry in Indonesia. Jurnal Ekonomi dan Kebijakan Pembangunan, 2(1), 1-13. http://journal.ipb.ac.id/index.php/jekp/article/view/19948/13740.

Vavra, P., Goodwin, B.K. (2005). Analysis of Price Transmission Along the Food Chain. OECD Food Agriculture and Fisheries Working Paper, No 3. Doi:10.1787/752335872456. http://www.oecd.org/Agriculture/Agriculturalpolicies/40459642.Pdf.

Verbeek M. 2000. A Guide to Modern Econometrics, third Edition. New York: John Wiley and Sons.

von Cramon-Taubadel, S., Loy, J.P. (1996). Price Asymmetry in the International Wheat Market: comment. Canadian Journal of Agricultural Economics 44(3):311-317. https://onlinelibrary.wiley.com/doi/epdf/10.1111/j.1744-7976.1996.tb00153.x. 